\title{
Physical and Meiotic Mapping of the Region of Human Chromosome 4q11-q13 Encompassing the Vitamin D Binding Protein DBP/Gc-Globulin and Albumin Multigene Cluster
}

\author{
Young-Han Song, ${ }^{1}$ Anna K. Naumova, ${ }^{1}$ Stephen A. Liebhaber, ${ }^{1,2}$ \\ and Nancy E. Cooke ${ }^{1,3}$ \\ Departments of Medicine, ${ }^{1}$ Genetics, and the ${ }^{2}$ Howard Hughes Medical Institute, University of Pennsylvania, \\ Philadelphia, Pennsylvania 19104 USA
}

\begin{abstract}
The vitamin D binding protein/Gc-globulin (DBP) gene is a member of a multigene cluster that includes albumin $(A L B), \alpha$-fetoprotein $(A F P)$, and $\alpha$-albumin/afamin (AFM). All four genes have structural and functional similarities and map to the same chromosomal regions in humans (4q11-q13), mice, and rats. An accurate physical map of the region encompassing these genes is a prerequisite for study of their respective transcriptional regulation and identification of potential shared regulatory elements. By refining the physical and meiotic maps of the 4q11-q13 region and creating a local PAC contig, the order and transcriptional orientations of these four genes were determined to be centromere-3'-DBP-5'-5'-ALB-3'-5'-AFP-3'-5'-AFM$3^{\prime}$-telomere. The ancestral $D B P$ gene was separated from the $A L B$ gene by $>1.5 \mathrm{Mb}$. This organization and spacing establishes a foundation for ongoing functional studies in this region.
\end{abstract}

Structurally related genes in higher eukaryotes with common evolutionary origins are frequently organized into multigene clusters. This organization may facilitate their coordinate expression by virtue of shared cisregulatory elements (for review, see Dillon and Grosveld 1993). The genes encoding vitamin D-binding protein (DBP; also known as the group-specific component, $G C)$, albumin $(A L B)$, $\alpha$-fetoprotein $(A F P)$, and $\alpha$-albumin/afamin (AFM) belong to a multigene family with highly conserved intron/exon organization and encoded protein structures (Cooke and David 1985; Yang et al. 1985; Belanger et al. 1994; Lichenstein et al. 1994). Evolutionary comparisons strongly support $D B P$ as the original gene in this group with subsequent local duplications generating the remaining genes in the cluster (Cooke and Haddad 1989, 1995; Haefliger et al. 1989). All four genes are expressed predominantly in the liver with overlapping developmental profiles. These data suggest that $D B P$ and the other members of the gene family may share one or more regulatory elements. Construction of a detailed physical map of the chromosomal region containing all four genes, including determination of relative transcriptional orientations, is a prerequisite for the study of this proposed coordinate regulation.

The closely linked, tandem arrangement of $A L B$ and $A F P$ in the same transcriptional orientation has been well documented in three mammalian species:

\footnotetext{
${ }^{3}$ Corresponding author.
}

E-MAIL necooke@mail.med.upenn.edu; FAX (215) 898-0189. mouse, rat, and man (Ingram et al. 1981; Chevrette et al. 1987; Urano et al. 1984, respectively). AFM, the most recently identified member of this gene family is located immediately downstream and in the same transcriptional orientation as the AFP gene in both man (Nishio et al. 1996) and rat (Belanger et al. 1994). Although studies showed that the $D B P$ gene is closely linked to the other three members of this gene family, it has not been possible to colocalize $D B P$ and any of these genes on a single yeast artificial chromosome (YAC) (Guan et al. 1996). Using fluorescent in situ hybridization (FISH) mapping on human stretched chromosomes, the four genes were reported to be organized as centromere-3'-DBP-5'-3'-AFM-5'-3'-AFP-5'-3'-ALB$5^{\prime}$-telomere and the distance between $D P B$ and $A F P$ was estimated to be $\sim 108 \mathrm{~kb}$ (Nishio et al. 1996). Using a new P1-artificial chromosome (PAC) contig and additional YACs, we report a refined and revised physical and meiotic map of the 4q11-q13 region. From these data it was concluded that the organization of the cluster is instead centromere-3'-DBP-5'-5'-ALB-3'-5' -AFP$3^{\prime}-5^{\prime}$-AFM-3'-telomere. In addition, these data revealed that the separation between $D B P$ and the remaining family members is at least $1.5 \mathrm{Mb}$.

\section{RESULTS}

Alignment of Physical and Meiotic Maps

The major genetic markers in the region of the $D B P$ gene are $D B P, A L B$, and $I L 8$. The existing meiotic maps 
either do not specify the order of the $D B P, A L B$, and $I L 8$ genes (GenLink; Marshfield Center for Medical Genetics; Cooperative Human Linkage Center) or else predict the gene order as centromere-DBP-IL8-ALB-telomere in the 4q11-q13 region (Mills et al. 1992; Fan et al. 1994) (Fig. 1A). In contrast, the physical map reports the inverted order, that is, centromere-DBP-ALB-IL8 (Stanford Human Genome Center; Karrman et al. 1997) (Fig. 1B). Many of the genes of interest (DBP, $A L B, A F P, A F M$, and IL8) do not contain convenient, highly polymorphic sequences. Therefore, to align the physical and meiotic maps we used microsatellite markers known to reside in close proximity to the $D B P$, $A L B$, and IL8 genes. PCR was performed to order three of these polymorphic markers, D4S2641, D4S1517, and D4S2403, using DNA from seven individuals from four Centre d'Etude du Polymorphisme Humain (CEPH) families (see Appendix I) (Fig. 1B,C, boxed). These seven individuals were known to have crossovers within the interval of interest between the bins
(D4S392/D4S2969/D4S1543) and (D4S2958/D4S2990/ D4S1558/D4S3042) (GenLink database). The crossovers in individuals 884-4 and 1362-11 indicated that D4S2641 lies distal to (D4S392/D4S2969/D4S1543) but proximal to (D4S1517/IL8/D4S2403) and (D4S2958/ D4S2990/D4S1558/D4S3042) (Fig. 1D). The crossovers within the individuals 884-12, 1332-3, 1347-3, and 1416-16 suggested that the markers D4S1517 and D4S2403 are proximal to the (D4S2958/D4S2990/ D4S1558/D4S3042) loci. The existing crossover data do not allow separation of markers D4S1517 and $\mathrm{D} 4 \mathrm{~S} 2403$. Thus, the order of these genetic markers was determined to be (D4S392/D4S2969/D4S1543/DBP)(D4S2641-ALB)-(D4S1517/IL8/D4S2403)-(D4S2958/ D4S2990/D4S1558/D4S3042) (Fig. 1C). This new order is consistent with that derived from the physical map (Stanford Human Genome Center; Karrman et al. 1997) (Fig. 1B) and excluded the possibility of inversion of the region between D4S1389 and D4S1558 (shown in brackets in Fig. 1B).

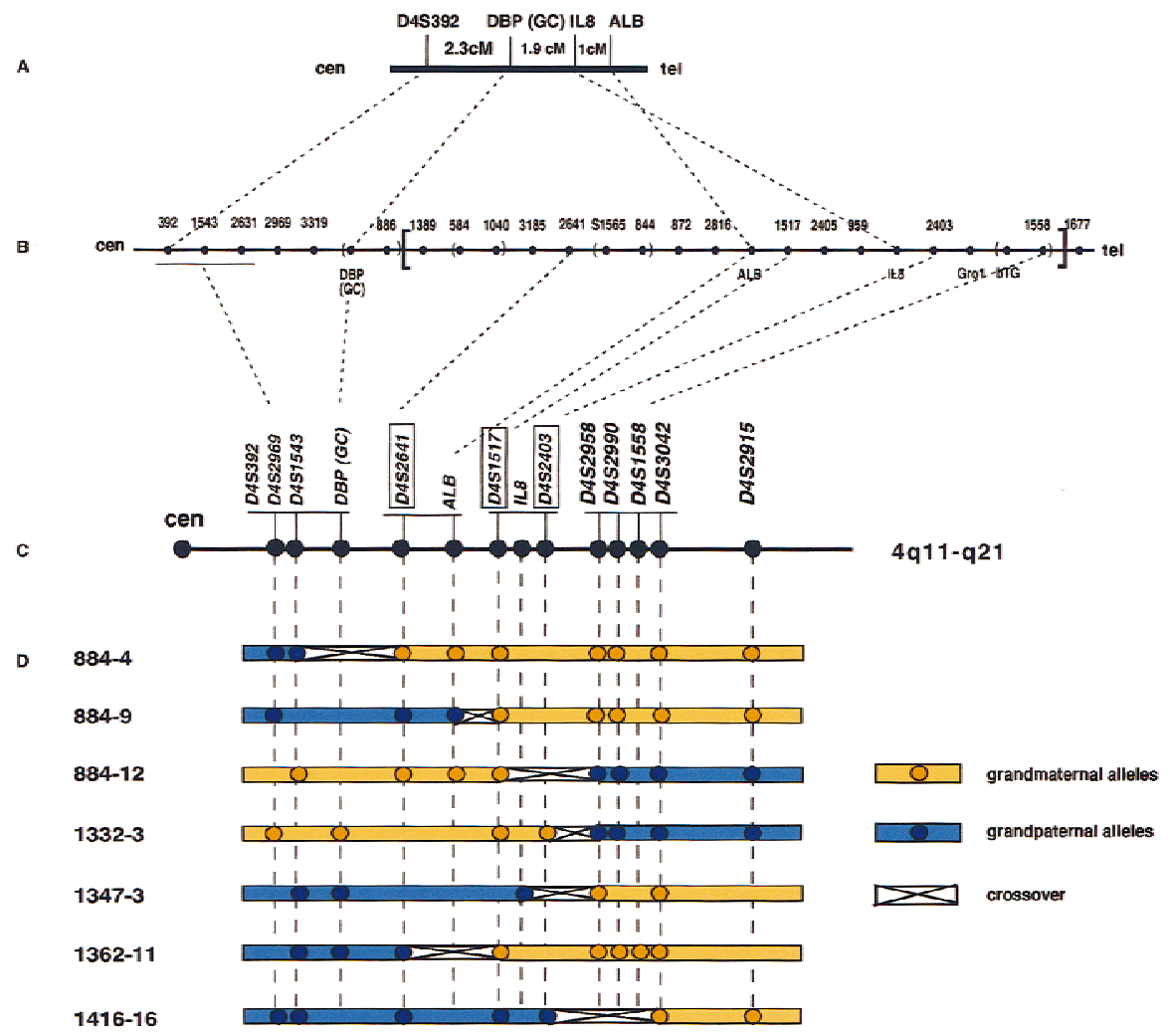

Figure 1 Genetic and physical maps of the subcentromeric region of chromosome 4. $(A)$ Genetic map (Fan et al. 1994); (B) physical map of 4q11-q21 (The Genome Database; Stanford Human Genome Center; Karrman et al. 1997). Lack of redundancy in this YAC contig suggested the possibility of an inversion of the interval enclosed in brackets. (C) Order of loci derived from the genotyping of CEPH families. The three markers tested in this study are boxed. Markers are underlined to indicate that there were no recombinants between them. $(D)$ Crossover map of $4 q 11-q 21$. DNA samples of seven individuals from CEPH families known to have a recombination between (D4S392/D4S2969/D4S1543) and (D4S2958/D4S2990/ D4S1558/D4S3042) were genotyped for markers D4S2641, D4S1517, and D4S2403, resulting in the deduced ordering shown in $C$.

\section{Orientation of $A L B / A F P / A F M$ Cluster}

The orientation of the $A L B / A F P /$ $A F M$ cluster relative to $D B P$ had not been defined by physical mapping. To determine the order of $D B P, A L B, A F P$, and $A F M$ genes, YAC clones containing these genes were characterized. The CEPH mega-YAC library was screened with primers for exon 4 of the $D B P$ gene and two YAC clones, 875G8 and 880F10, were isolated. These and a series of YAC clones reported to contain the $A L B, I L 8$, or $D B P$ genes (Fan et al. 1994) were analyzed (summarized in Table 1). The sizes of the YACs were determined by pulsed-field gel electrophoresis (PFGE) followed by hybridization with total human DNA. YACs $325 \mathrm{C} 3$ and 218B4 generated two bands when hybridized with total human DNA suggesting that they contained two YACs. Each YAC was tested for its chromosome content by the Alu-PCR method. Of 14 YACs, 4 were found to be chimeric, containing DNA from chromosomes 1, 2, 3, 8 , or 14 in addition to chromosome 4 . To confirm the chromosome content determined by $A l u-P C R$, FISH was performed on 
Table 1. Characterization of DBP-, ALB-, and IL8-Containing YACs

\begin{tabular}{|c|c|c|c|c|c|c|c|c|c|c|}
\hline \multirow[b]{2}{*}{ YAC } & \multirow[b]{2}{*}{ Size (kb) } & \multicolumn{2}{|c|}{ Chromosome } & \multirow[b]{2}{*}{$D_{B P}^{a, b}$} & \multirow[b]{2}{*}{$\mathrm{ALB}^{\mathbf{b}}$} & \multirow[b]{2}{*}{$A F P^{b}$} & \multirow[b]{2}{*}{ AFM $^{b}$} & \multirow[b]{2}{*}{ IL8 $^{b}$} & \multirow[b]{2}{*}{ Gro1 $^{b}$} & \multirow[b]{2}{*}{$\beta T C^{b}$} \\
\hline & & Alu-PCR & FISH & & & & & & & \\
\hline $300 C 7$ & 360 & 4 & & + & - & - & - & - & - & - \\
\hline $331 \mathrm{G} 3$ & 290 & 4 & & + & - & - & - & - & - & - \\
\hline $875 G 8$ & 1700 & 4 & 4 & + & - & - & - & - & - & - \\
\hline $880 F 10$ & 750 & $1,3,4$ & & + & - & - & - & - & - & - \\
\hline 879B11 & 1500 & 4 & & - & - & - & - & - & - & - \\
\hline $879 C 3$ & 1500 & 4 & & - & - & - & - & - & - & - \\
\hline yWPR22 & 720 & 2,4 & 2,4 & - & + & + & + & + & - & - \\
\hline $250 \mathrm{C} 8$ & 365 & 4 & & - & + & + & + & - & - & - \\
\hline $325 C 3$ & $280 / 410$ & 4 & & - & + & $+^{*}$ & + & - & - & - \\
\hline $335 G 4$ & 450 & 4 & & - & + & + & + & - & - & - \\
\hline 379D4 & 350 & 4,8 & & - & - & - & + & + & - & - \\
\hline 218B4 & $360 / 440$ & 4,14 & & - & - * & - * & - & $t^{*}$ & - & - \\
\hline 216D5 & 355 & 4 & & - & - & - & - & + & - & - \\
\hline $42 \mathrm{~F} 3$ & 360 & 4 & & - & - & - & - & + & + & + \\
\hline
\end{tabular}

aPCR was performed to assign the genes to each YAC. The DBP (exon 4) primer was used (Table 3).

$\mathrm{b}(+)$ The presence of a signal of the expected size; $(-)$ no amplification; $\left(^{*}\right)$ discrepancy with published results.

YAC clones $875 \mathrm{G} 8$ and yWPR22. FISH data confirmed that the $875 \mathrm{G} 8$ insert contained DNA only from chromosome 4, whereas yWPR22 hybridized to chromosome 2 and chromosome 4 (data not shown). The most recently identified gene, $A F M$, has not been localized in the previous YAC contig (Stanford Human Genome Center). To determine the orientation of the $A L B / A F P /$

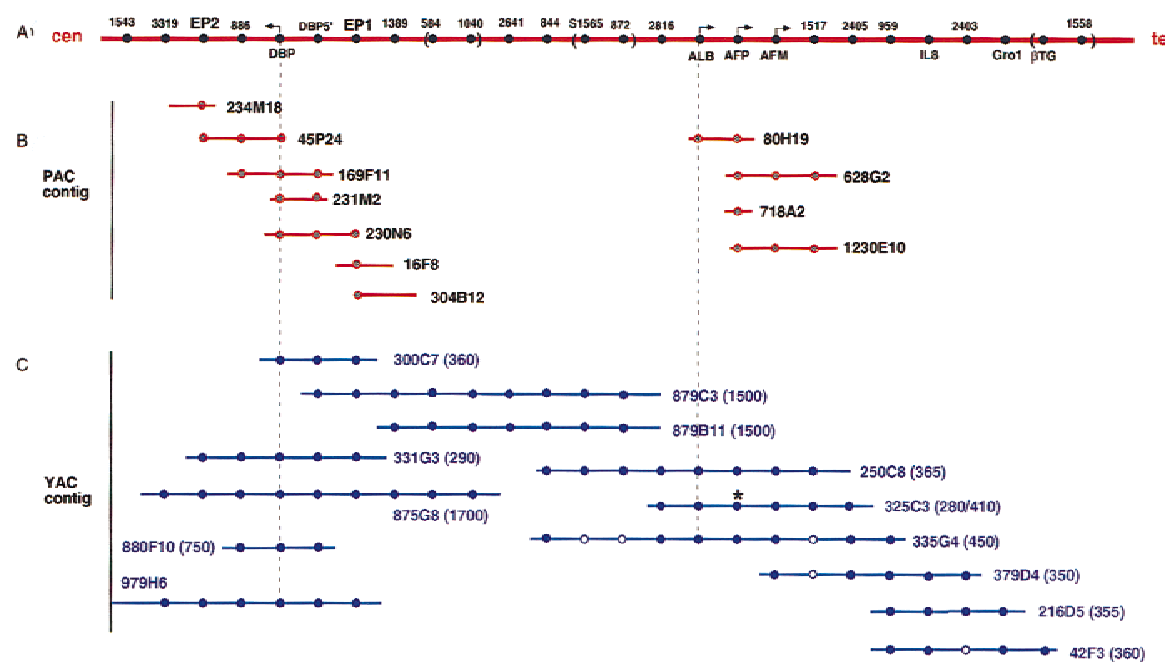

Figure 2 Schematic diagram of the human chromosome 4q11-q21 region deduced from P1/PAC and YAC contigs. ( $A$ ) The order of markers determined from previous (Stanford Human Genome Center; Karrman et al. 1997) and present data are shown. The distances between the markers are not drawn to scale, and the orders of STS markers enclosed by parentheses were not determined. Markers are indicated without the D4S designation. The angled arrows indicate the transcriptional directions of the genes. (B) Contigs of bacteriophage P1/PAC clones in the $D B P$ gene region and in region of the $A L B / A F P / A F M$ gene cluster isolated for this study. (C) YAC contig linking the DBP gene with the ALB/AFP/AFM gene cluster from previous (Stanford Human Genome Center; Karrman et al. 1997) and present data. The sizes of each YAC clone are indicated in parentheses. All the markers shown were tested for each YAC. A solid circle indicates the presence of the STS or the gene shown in A. An open circle indicates that the presence of that marker could not be confirmed in our experiments. An asterisk $\left(^{*}\right)$ indicates that our results were discrepant with the literature.
$A F M$ cluster, primers specific for $A F M$ as well as $A L B$ and $A F P$ were used to test the presence of these genes in each YAC. All of the YAC clones containing $A L B$ also contained $A F P$ and $A F M$ and therefore did not provide additional information about the order of the genes within the cluster with respect to the centromere. One YAC clone, 379D4, was potentially informative: It contained $A F M$ but not $A L B$ and $A F P$ genes. Unfortunately, this clone was found to be chimeric and to have a deletion within the chromosome 4 insert (see Fig. 2). Therefore it could not be used for determination of the order of the $A L B, A F P$, and $A F M$ genes.

To address this problem we screened bacteriophage P1/PAC libraries to generate a P1/PAC contig in the $A L B$ region. One PAC clone $(80 \mathrm{H} 19)$ and three P1 clones $(628 \mathrm{G} 2,718 \mathrm{~A} 2$, and 1230E10) were selected using primers specific for the $A F P$ gene. All four clones were tested for the presence or absence of $A L B, A F M$, and neighboring markers. $80 \mathrm{H} 19$ contained $A L B$ but not $A F M$, whereas $628 \mathrm{G} 2$ and $1230 \mathrm{E} 10$ contained $A F M$ and D4S1517 but not $A L B$ (Fig. 2A,B). Because D4S1517 was mapped distal to $A L B$ in both the previous physical map (Stanford Human Genome Center, Fig. 1B) and our meiotic map 
(Fig. 1D, see individual 884-9), the P1/PAC contig data placed $A F M$ distal to $A L B$ and $A F P$ and next to D4S1517. AFP mapped distal to $A L B$ and proximal to $A F M$. Because the head-to-tail transcriptional orientation of the $A L B, A F P$, and $A F M$ genes in both human and in rat had been established previously (Belanger et al. 1994; Nishio et al. 1996), the order of the genes is centromere-DBP-5' -ALB-3'-5' -AFP-3' - 5' -AFM-3' telomere (Fig. 2).

\section{Transcriptional Orientation of the DBP Gene}

To determine the transcriptional orientation of the $D B P$ gene a chromosome walking strategy combined with construction of PAC and YAC contigs in the DBP gene region were utilized. Four PAC clones containing exon 4 of the $D B P$ gene were isolated from the human PAC library (Genome Systems, Inc., St. Louis, MO). Two PAC clones $169 \mathrm{~F} 11$ and 45P24 containing the DBP gene were positive for D4S886 (Fig. 2B). End sequencing of PAC 45P24 demonstrated that PAC 45P24 lacked 1680 bp of the $5^{\prime}$-flanking $D B P$ sequence. Two other clones $230 \mathrm{~N} 6$ and $231 \mathrm{M} 2$ contained the $5^{\prime}$-flanking region but not D4S886. Hence, the order of markers was determined as $5^{\prime}$-DBP-3'-D4S886 (Fig. 2A).

New sets of primers were designed using the DNA end sequences of PAC clones 230N6 (EP1, most distant $5^{\prime}$ from $D B P$ ) and 45P24 (EP2, most distant 3' from $D B P$ ) and the PAC contig was extended in both directions with PAC clones $234 \mathrm{M} 18$ (centromeric) and 16F8 and 304B12 (telomeric). The presence or absence of eleven PCR markers was tested in five YAC clones (Table 2). These YAC clones were reported previously to contain the $D B P$ gene and/or flanking STS markers D4S3319 (centromeric to DBP) and D4S1389 (telomeric to $D B P$ ) (Stanford Human Genome Center; Karrman et al. 1997; The Genome Database). Clone 879C3 was negative for D4S3319, D4S886, and DBP gene markers for exons 11, 9 and 4 (Tables 1 and 2); it was positive for the DBP 5 '-flanking region, EP1, exon 1, and the telomeric marker D4S1389 (Table 2; Fig. 2C). These data indicate that the transcriptional orientation of the $D B P$ gene is centromere-3'-DBP-5'-telomere, op- posite to the transcriptional orientations of the $A L B$, $A F P$, and AFM genes (Fig. 2A).

\section{The Minimal Distance Between the DBP and $A L B$ Genes}

Although none of the YAC clones contained both the $D B P$ and $A L B$ genes (see Table 1), two YACs, 879C3 and 879B11, linked DBP-containing YAC 875G8 and ALBcontaining YAC 250C8 (Stanford Human Genome Center) (Fig. 2C). No chimerism was found in these two linking YACs when they were tested for chromosomal content by Alu-PCR. The sizes of YACs 879C3 and $879 \mathrm{~B} 11$ were determined by PFGE and both were $\sim 1500 \mathrm{~kb}$ (Table 1). Thus, the distance between DBP and the $A L B / A F P / A F M$ cluster is a minimum of $1.5 \mathrm{Mb}$.

\section{DISCUSSION}

In this study, we refined the genetic map at the $D B P$ multigene locus by characterization of a YAC contig, generation of P1/PAC contigs, and meiotic mapping. The discrepancy between the existing meiotic and physical maps required special analyses. Because only one YAC (875G8) was identified in our study that bridged both the DBP-D4S886 region and D4S1389 (Fig. 2C), and there was no established YAC contig distal to D4S1558, the possibility that the region between D4S1389 and D4S1558 was inverted initially could not be excluded. If this region were inverted, the order of the $D B P, A L B$, and IL8 genes would be consistent with the earlier genetic maps (Fig. 1A) (Mills et al. 1992; Fan et al. 1994). Further characterization of the YACs identified YAC clone $879 \mathrm{C} 3$ that contained the marker D4S1389 and $D B P$ exon 1, thus orienting this region as shown in Figure 2A. In addition, our meiotic mapping also eliminated the possibility of inversion and in conjunction with the contigs, the order of the genes was determined to be centromere-3'-DBP-5'-5'-ALB-3'-5'AFP-3'-5'-AFM-3'-telomere.

This gene order differed from the conclusions of Nishio et al. (1996), carried out by FISH hybridization to extended DNA fibers. Their data predicted that all four genes were in the same transcriptional orientation in the order centromere-3'-DBP-5'-3'-AFM-5'-3'-AFP-

Table 2. STS Content of YAC Clones and Transcriptional Orientation of the DBP Gene

\begin{tabular}{|c|c|c|c|c|c|c|c|c|c|c|c|}
\hline \multirow[b]{2}{*}{ Clone } & \multirow[b]{2}{*}{ D4S3319 } & \multirow[b]{2}{*}{ EP2 } & \multirow[b]{2}{*}{ D4S886 } & \multicolumn{2}{|c|}{ Exon } & \multirow{2}{*}{$\begin{array}{c}\text { DBP } \\
\text { intron } 6\end{array}$} & \multicolumn{2}{|c|}{ Exon } & \multirow{2}{*}{$\begin{array}{c}\text { DBP } \\
5^{\prime}\end{array}$} & \multirow[b]{2}{*}{ EP1 } & \multirow[b]{2}{*}{ D4S1389 } \\
\hline & & & & 11 & 9 & & 4 & 1 & & & \\
\hline $979 \mathrm{H} 6$ & + & + & + & + & + & N.T. & + & + & + & + & - \\
\hline $875 G 8$ & + & + & + & + & + & + & + & + & + & + & + \\
\hline $331 \mathrm{G} 3$ & - & + & + & + & + & + & + & + & + & + & - \\
\hline $300 C 7$ & - & - & - & - & - & - & + & + & + & + & - \\
\hline $879 C 3$ & - & - & - & - & - & N.T. & - & + & + & + & + \\
\hline
\end{tabular}

(+) Presence of marker; (-) absence of marker; (N.T.) presence of marker not tested. 
5'-3'-ALB-5'-telomere. This order was deduced from five different FISH mapping experiments using probes specific for the human chromosome 4 centromere, $A L B, D B P 5^{\prime}$ end, $D B P$ 3' end, $A F P, A F M 5^{\prime}$ end, and $A F M 3^{\prime}$ end. Specifically, the following orders of several subgroups of these genes were determined: $A L B-D B P-$ centromere, $A L B-A F P-A F M, A F P-A F M-5^{\prime}-A F M-3^{\prime}$, $A F P-D B P-5^{\prime}-D B P-3^{\prime}$, and $A L B-A F P-D B P$. All of the FISH mapping experiments were performed on extended DNA fibers except for the ordering of $A L B-D B P-$ centromere where mechanically stretched chromosome were used. The gene orders, predicted from the first four of these FISH mapping experiments, are consistent with our data. The discrepancy results from the predicted order $A L B-A F P-D B P$ that was determined by hybridization to extended DNA fibers. Although these high-resolution FISH techniques allow ordering of two or more markers, interphase mapping is most useful for estimating genomic separations $<1 \mathrm{Mb}$ (Trask 1991). However, nonrandom loops and folds in interphase chromatin may give rise to a frequently observed but incorrect order (Yokota et al. 1995). Considering the large distance (minimum $1.5 \mathrm{Mb}$ ) between $D B P$ and $A L B$ determined in the present study, FISH mapping on DNA fibers may not be the ideal method for determining the order of $D B P, A L B$, and $A F P$ genes. Similar discrepancies between FISH and physical mapping have been reviewed elsewhere (Mendez et al. 1994).

As members of a gene family, $D B P, A L B, A F P$, and $A F M$ have been shown to share several structural simi-

Table 3. Sequences of Primer Sets Used in this Study

DBP5' ( $5^{\prime}$-flanking region)
237 bp
DBP E1 ${ }^{\mathrm{a}}$ (exon 1)
157 bp
DBP (exon 4)
212 bp
DBP (intron 6)
172 bp
E9 $9^{\mathrm{a}}$ (exon 9$)$
239 bp
E11 ${ }^{\mathrm{a}}$ (exon 11)
249 bp
EP1 ${ }^{\mathrm{b}}$
203 bp
EP2
252 bp
AFP (exon 12)
224 bp
AFM (1790-1878
88 bp

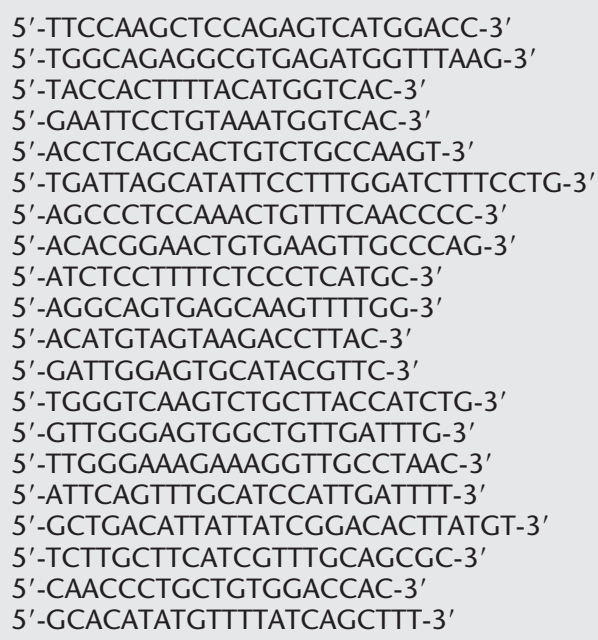

aYuasa et al. (1995).

${ }^{b}$ EP1 and EP2 are the end sequences of the inserts of PAC clones 230N6 and 45P24, respectively.

'The number in parenthesis is the nucleotide number of the AFM CDNA (Lichenstein et al. 1994). The sizes of the amplified fragments are indicated below the names of primers. larities. These proteins share a common three-domain cture defined by the invariant positions of cysteine that are cross-linked by disulfide bonds coding region has also been conserved as a characeristic feature of this gene family (Ray et al. 1991). Of four genes, the $D B P$ gene is the most divergent of the $D B P$ gene and an $A B / A F P / A F M$ P g gene (Haefliger et al. 1989). Later, the $A L B$ gene was enerated by duplication of the $A L B / A F P / A F M$ primor$D B P$, is separated from the other mum distance of $1500 \mathrm{~kb}$. In addition, its transciponal orientation is inverted relative to the other three This orientation places the $D B P$ gene and the 作 METHODS

Restriction and modification enzymes were purchased from New England Biolabs Inc. (Beverly, MA). The chemicals were purchased from Sigma Chemical Co. (St. Louis, MO), unless otherwise indicated. Taq DNA polymerase was purchased from Boehringer-Mannheim Corp. (Indianapolis, IN). Oligonucleotides were synthesized by GIBCO BRL Life Technologies (Gaithersburg, MD) or purchased from Research Genetics, Inc. (Huntsville, AL). DNA samples from the CEPH families were kindly provided by Drs. K. Fischbeck and K. Gogolin Ewens (University of Pennsylvania School of Medicine, Philadelphia).

\section{Sequence-Tagged Sites}

The sequence-tagged sites (STSs) for the $A L B, I L 8$, and Gro1 genes correspond to STS4-97, STS4-1009, and STS4-1010, respectively (Goold et al. 1993). The sequences of primers used to detect $A F P, A F M$, and regions of the $D B P$ gene $\left(5^{\prime}\right.$-flanking region, exon 1 , exon 4 , intron 6 , exon 9 , and exon 11) are shown in Table 3. PCR primers for the 5 '-flanking region, exon 4 , and intron 6 of the $D B P$ gene were designed on the basis of the published sequence of DBP (GenBank accession no. L10641). PCR assay for the $\beta$-thromboglobulin ( $\beta$ TG) was performed as described (Majumdar et al. 1991). The 
marker S1516 was generated by the Stanford Human Genome Center.

\section{YACs}

The CEPH mega-YAC library was screened using a PCR assay for exon 4 of the $h D B P$ gene (Table 3). YAC clone yWPR22 containing the $A L B$ gene was obtained from B. Brownstein (Center for Genetics in Medicine, Washington University, School of Medicine, St. Louis, MO). YAC clones 879B11 and 879C3 were purchased from Genome Systems, Inc. (St. Louis, $\mathrm{MO}$ ). The rest of the YACs were provided by C. Bell (University of Pennsylvania, Philadelphia, PA).

\section{Screening of Human P1/PAC Libraries}

Human P1/PAC libraries were screened for $D B P$ with primers for $D B P 5$ ', intron 6, exon 9, and exon 11 and for $A F P$ (Table 3) by Genome Systems, Inc. Sequencing of the PAC clone insert ends using T7 and SP6 primers was performed by the DNA sequencing facility of the University of Pennsylvania.

\section{Preparation of YAC DNA}

YAC DNA was prepared either in agarose blocks or in solution as described (Mendez et al. 1994).

\section{Determination of the Sizes and STS Content of YACs}

PFGE was performed using a Bio-Rad DRII clamped homogeneous electric field (CHEF) apparatus (Bio-Rad Laboratories, Hercules, CA). One-third of each YAC plug was loaded onto $1 \%$ SeaKem LE agarose gels (FMC BioProducts, Rockland, ME) and was electrophoresed in $0.5 \times \mathrm{TBE}$ at $14^{\circ} \mathrm{C}$. Size standards included commercial preparations of Saccharomyces cerevisiae chromosomes (Bio-Rad Laboratories) and a $\lambda$ phage DNA ladder (New England Biolabs, Inc., Beverly, MA). DNA fragments between 50 and $2000 \mathrm{~kb}$ were fractionated using a ramp from 50 to $90 \mathrm{sec}$ over $24 \mathrm{hr}$ at $200 \mathrm{~V}$. Gels were Southern blotted onto Zetabind membrane (CUNO, Inc., Meriden, CT) in $10 \times$ SSC. The prehybridization and hybridization were performed in $0.5 \mathrm{~m}$ sodium phosphate buffer at $\mathrm{pH} 7.2,1 \% \mathrm{BSA}, 1 \mathrm{~mm}$ EDTA, 7\% SDS, and $200 \mu \mathrm{g} / \mathrm{ml}$ sonicated salmon sperm DNA. The membrane was hybridized with total human DNA labeled using a random-primer labeling kit (Boehringer Mannheim Corp.). STS content of the YAC clones was determined by PCR of total yeast DNA.

\section{Determination of YAC Chimerism}

To determine whether the YAC inserts were chimeric for human DNA from more than one chromosome, Alu-PCR dot blot hybridizations were performed by vectorette PCR as described previously (Zoghbi and Chinault 1994). The human/ rodent somatic cell hybrid DNA panel was purchased from the Coriell Institute (Camden, NJ, panel 2). The DNA sequence of the $A l u$ primer, primer PDJ34, is $5^{\prime}-\mathrm{TGAGC}(\mathrm{C} / \mathrm{T})(\mathrm{G} /$ A) $(\mathrm{A} / \mathrm{T}) \mathrm{GAT}(\mathrm{C} / \mathrm{T})(\mathrm{G} / \mathrm{A})(\mathrm{C} / \mathrm{T})(\mathrm{G} / \mathrm{A}) \mathrm{CCA}(\mathrm{C} / \mathrm{T}) \mathrm{TGCACTC}-$ CAGCCTGGG-3'. To block repetitive sequences the labeled probe was preassociated with human Cot-1 DNA (GIBCO BRL Life Technologies, Inc.) following the manufacturer's instructions. In addition, repetitive sequences were competed by adding sheared human placental DNA to the prehybridization mix at a concentration of $0.1 \mathrm{mg} / \mathrm{ml}$.

\section{Meiotic Mapping}

The order of the markers D4S1517, D4S2641, and D4S2403 was determined using DNA samples from five CEPH families.
Seven individuals from the five CEPH families known to have crossovers within the region of interest (families 884, 1332, 1347, 1362, and 1416; GenLink database) were scored for D4S1517, D4S2641, and D4S2403. PCR was performed with DNA samples using trace amount of $\left[\alpha-{ }^{32} \mathrm{P}\right] \mathrm{dCTP}$. PCR products were separated by $5 \%$ denaturing polyacrylamide gel electrophoresis. Gels were exposed to an X-ray film. Grandparental origins of the D4S1517, D4S2641, and D4S2403 alleles were determined by the differences in the sizes of the polymorphic PCR products from the individual, parents, and grandparents. Genotypes for the same 7 individuals for $D B P /$ $G C, A L B, I L 8$, and D4S2389 were obtained from the CEPH genotype database and for D4S392, D4S1543, D4S2958, D4S2990, D4S1558, and D4S2915 from the GenLink database.

\section{ACKNOWLEDGMENTS}

This work was supported by National Institutes of Health grants R01 GM32035 (N.E.C.) and T32 AR07481 (A.K.N.). We thank Dr. Nancy Spinner for FISH analysis and Dr. Pei Fu He for technical support.

The publication costs of this article were defrayed in part by payment of page charges. This article must therefore be hereby marked "advertisement" in accordance with 18 USC section 1734 solely to indicate this fact.

\section{REFERENCES}

Belanger, L., S. Roy, and D. Allard. 1994. New albumin gene 3' adjacent to the $\alpha 1$-fetoprotein locus. J. Biol. Chem. 269: $5481-5484$.

Brown, J.R. 1976. Structural origins of mammalian albumin. Fed. Proc. 35: 2141-2144.

Chevrette, M., M. Guertin, B. Turcotte, and L. Belanger. 1987. The rat $\alpha 1$-fetoprotein gene: Characterization of the 5 '-flanking region and tandem organization with the albumin gene. Nucleic Acids Res. 15: 1338-1339.

Cooke, N.E. and E.V. David. 1985. Serum vitamin D-binding protein is a third member of the albumin and alpha-fetoprotein gene family. J. Clin. Invest. 76: 2420-2424.

Cooke, N.E. and J.G. Haddad. 1989. Vitamin D-binding protein (Gc-globulin). Endocr. Rev. 10: 294-307.

- 1995. Vitamin D-binding protein (Gc-globulin): Update 1995. Endocr. Rev. 4: 125-128.

Dillon, N. and F. Grosveld. 1993. Transcriptional regulation of multigene loci: Multilevel control. Trends Genet. 9: 134-137.

Fan, J.B., J. DeYoung, R. Lagace, R.A. Lina, Z. Xu, J.C. Murray, K.H. Buetow, J. Weissenbach, R.D. Goold, D.R. Cox, and R.M. Myers. 1994. Isolation of yeast artificial chromosome clones from 54 polymorphic loci mapped with high odds on human chromosome 4. Hum. Mol. Genet. 3: 243-246.

Goold, R.D., G.L. diSibio, H. Xu, D.B. Lang, J. Dadgar, G.G. Magrane, A. Dugaiczyk, K.A. Smith, D.R. Cox, S.B. Masters, and R.M. Myers. 1993. The development of sequence-tagged sites for human chromosome 4. Hum. Mol. Genet. 2: 1271-1288.

Guan, X.J., G. Arhin, and S.M. Tilghman. 1996. Linkage between vitamin D-binding protein and $\alpha$-fetoprotein in the mouse. Mamm. Genome 7: 103-106.

Haefliger, D.N., J.E. Moskaitis, D.R. Schoenberg, and W. Wahli. 1989. Amphibian albumin as members of the albumin, $\alpha$-fetoprotein, vitamin D-binding protein multigene family. $J$. Mol. Evol. 29: 344-354.

Ingram, R.S., R.W. Scott, and S.M. Tilghman. 1981. $\alpha$-fetoprotein and albumin genes are in tandem in the mouse genome. Proc. Natl. Acad. Sci. 78: 4694-4698.

Karrman, C., B. Backman, M. Dixon, G. Holmgren, and K. Forsman. 1997. Mapping of the locus for autosomal dominant amelogenesis imperfecta (AIH2) to a 4-Mb YAC contig on chromosome 4q11-q21. Genomics 39: 164-170. 
Lichenstein, H.S., D.E. Lyons, M.M. Wurfel, D.A. Johnson, M.D. McGinley, J.C. Leidli, D.B. Trollinger, J.P. Mayer, S.D. Wright, and M.M. Zukowski. 1994. Afamin is a new member of the albumin, $\alpha$-fetoprotein, and vitamin D-binding protein gene family. J. Biol. Chem. 269: 18149-18154.

Majumdar, S., D. Gonder, B. Koutsis, and M. Poncz. 1991. Characterization of the human $\beta$-thromboglobulin gene. J. Biol. Chem. 266: 5785-5789.

Mendez, M., P. Erickson, P. Scott, H.A. Drabkin, and R.M. Gemmill. 1994. Chapter 4. Isolation of YAC clones from genomic libraries by Southern blot hybridization. In YAC libraries: A user's guide (ed, D.L. Nelson and B.H. Brownstein), pp. 57-91. W.H. Freeman and Company, New York, NY.

Mills, K.A., K.H. Buetow, Y. Xu, J.L. Weber, M.R. Altherr, J.J. Wasmuth, and J.C. Murray. 1992. Genetic and physical maps of human chromosome 4 based on dinucleotide repeats. Genomics 14: 209-219.

Nishio, H., M. Heiskanen, A. Palotie, L. Belanger, and A. Dugaiczyk. 1996. Tandem arrangement of the human serum albumin multigene family in the sub-centromeric region of 4q: evolution and chromosomal direction of transcription. J. Mol. Biol. 259: 113-119.

Ray, K., X. Wang, M. Zhao, and N.E. Cooke. 1991. The rat vitamin D binding protein (Gc-globulin) gene: Structural analysis, functional, and evolutionary correlation. J. Biol. Chem. 266: 6221-6229.

Trask, B.J. 1991. Gene mapping by in situ hybridization. Curr. Opin. Genet. Dev. 1: 82-87.

Urano, Y., M. Sakai, K. Watanabe, and T. Tamaoki. 1984. Tandem arrangement of the albumin and $\alpha$-fetoprotein genes in the human genome. Gene 32: 255-261.

Yang, F., J.L. Brune, S.L. Naylor, R.L. Cupples, K.H. Naberhaus, and B.H. Bowman. 1985. Human group-specific component (Gc) is a member of the albumin family. Proc. Natl. Acad. Sci. 82: 7994-7998.

Yokota, H., G. van den Engh, J.E. Hearst, R.K. Sachs, and B.J. Trask. 1995. Evidence for the organization of chromatin in megabase pair-sized loops arranged along a random walk path in the human G0/G1 interphase nucleus. J. Cell Biol. 130: 1239-1249.

Yuasa, I., A. Kofler, A. Braun, K. Umetsu, R. Bichlmaier, S. Kammerer, and H. Cleve. 1995. Characterization of mutants of the vitamin D-binding protein/group-specific component: Molecular evolution of $\mathrm{GC}^{\star} 1 \mathrm{~A} 2$ and $\mathrm{GC}^{\star} 1 \mathrm{~A} 3$, common in some Asian populations. Hum. Genet. 95: 507-512.

Zoghbi, H.Y. and A.C. Chinault. 1994. Chapter 5. Generation of YAC contigs by walking. In YAC libraries: A user's guide (ed. D.L. Nelson and B.H. Brownstein), pp. 93-112. W.H. Freeman and Company, New York, NY.

Received November 17, 1998; accepted in revised form March 31, 1999.

\section{Appendix I. Electronic Databases Used}

1. CEPH: http://www.cephb.fr

2. Cooperative Human Linkage Center: http:// www.chlc.org

3. GenLink: http://www.genlink.wustl.edu

4. Marshfield Medical Center: http://www.marshmed. org/genetics

5. Stanford Human Genome Center: http://shgc-www. stanford.edu

6. The Genome Database: http://gdbwww.gdb.org 


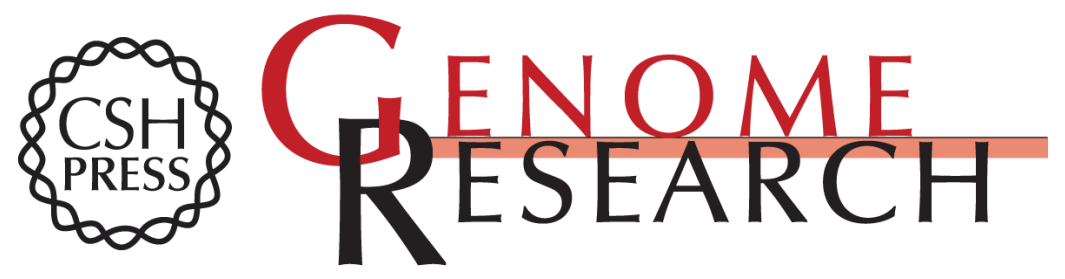

\section{Physical and Meiotic Mapping of the Region of Human Chromosome 4q11-q13 Encompassing the Vitamin D Binding Protein DBP/Gc-Globulin and Albumin Multigene Cluster}

Young-Han Song, Anna K. Naumova, Stephen A. Liebhaber, et al.

Genome Res. 1999 9: 581-587

Access the most recent version at doi:10.1101/gr.9.6.581

References This article cites 21 articles, 7 of which can be accessed free at: http://genome.cshlp.org/content/9/6/581.full.html\#ref-list-1

License

Email Alerting

Receive free email alerts when new articles cite this article - sign up in the box at the Service top right corner of the article or click here.

\section{Affordable, Accurate Sequencing.}

